\title{
Good Practices in Transitional Care: continuity of care for patients undergoing liver transplantation
}

\author{
Boas Práticas no Cuidado Transicional: continuidade da assistência ao paciente submetido ao transplante de fígado
}

Buenas Prácticas en la Atención Transicional: continuidad de la atención de los pacientes sometidos a trasplante de hígado

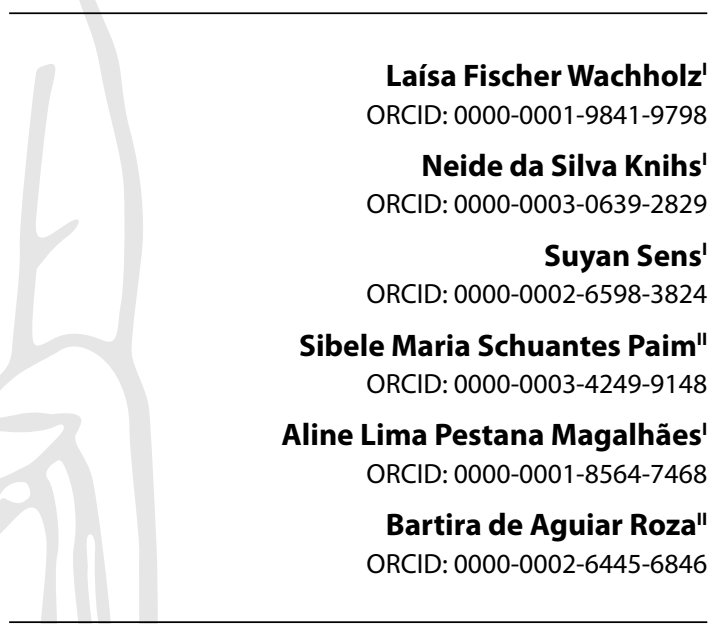

'Universidade Federal de Santa Catarina. Florianópolis, Santa Catarina, Brazil.

"Universidade Federal de São Paulo. São Paulo,

São Paulo, Brazil.

How to cite this article: Wachholz LF, Knihs NS, Sens S, Paim SMS, Magalhães ALP, Roza BA. Good Practices in Transitional Care: continuity of care for patients undergoing liver transplantation.

Rev Bras Enferm. 2021;74(2):e20200746. https://doi.org/10.1590/0034-7167-2020-0746

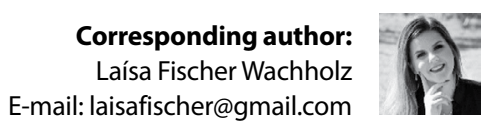

EDITOR IN CHIEF: Antonio José de Almeida Filho ASSOCIATE EDITOR: Fátima Helena Espírito Santo

Submission: $07-30-2020$

Approval: $11-21-2020$

\section{ABSTRACT}

Objectives: to develop a guide of care recommendations for good practices in care transition for adult patients undergoing liver transplantation. Methods: a methodological study, based on the Appraisal of Guidelines for Research \& Evaluation in the updated version, II. Care recommendations were sustained by conducting an integrative literature review and qualitative research. Results: from evidence, three topics emerged: Care Transition Planning; Health Education for Self-Care; Care Management. Each of the central topics has respective subtopics, totaling six, giving rise to 30 care recommendations. Concerning evaluators'scores, in all domains the scores were higher than $90 \%$. Final Considerations: the proposed guide assists professionals in conducting care transition in liver transplantation, ensuring greater safety for patients in continuity of home care.

Descriptors: Transplant; Liver Transplant; Continuity of Patient Care; Nursing; Nursing Education.

\section{RESUMO}

Objetivos: elaborar um guia de recomendações de cuidados para boas práticas na transição do cuidado de pacientes adultos submetidos ao transplante hepático. Métodos: estudo metodológico, tendo como referencial o Appraisal of Guidelines for Research \& Evaluation na versão atualizada, II. Sustentaram-se as recomendações de cuidados por meio da realização de uma revisão integrativa da literatura e uma pesquisa qualitativa. Resultados: a partir das evidências, oportunizou a formação de três tópicos: Planejamento da Transição do Cuidado; Educação em Saúde para o Autocuidado; Gestão dos Cuidados. Cada um dos tópicos centrais apresenta respectivos subtópicos, totalizando seis, originando 30 recomendações de cuidados. No que se refere à pontuação dos escores pelos avaliadores, em todos os domínios os escores foram superiores a $90 \%$. Considerações Finais: o guia proposto auxilia os profissionais na condução da transição do cuidado no transplante hepático, garantindo maior segurança aos pacientes na continuidade do cuidado em domicílio.

Descritores: Transplante; Transplante de Fígado; Continuidade da Assistência ao Paciente; Enfermagem; Educação em Enfermagem.

\section{RESUMEN}

Objetivos: desarrollar una guía de recomendaciones asistenciales de buenas prácticas en la transición asistencial para pacientes adultos sometidos a trasplante hepático. Métodos: estudio metodológico, utilizando el Appraisal of Guidelines for Research \& Evaluation en la versión actualizada, II. Las recomendaciones de atención se sustentaron mediante la realización de una revisión integradora de la literatura y una investigación cualitativa. Resultados: con base en la evidencia, permitió la formación de tres temas: Planificación de la Transición del Cuidado; Educación Sanitaria para el Autocuidado; Administración de Cuidados. Cada uno de los temas centrales tiene subtemas respectivos, totalizando seis, dando lugar a 30 recomendaciones de cuidados. En cuanto a la puntuación de las puntuaciones de los evaluadores, en todos los dominios las puntuaciones fueron superiores al $90 \%$. Consideraciones Finales: la guía propuesta ayuda a los profesionales a realizar la transición de la atención en el trasplante de hígado, garantizando una mayor seguridad para los pacientes en la continuidad de la atención domiciliaria.

Descriptores: Trasplante; Trasplante de Hígado; Continuidad de la Atención al Paciente; Enfermería; Educación de Enfermería. 


\section{INTRODUCTION}

In the last five years (2015-2019), in Brazil, there was a $22 \%$ increase in the number of adult liver transplantations (THx) performed, going from 1,660 to 2,087. This awakens in the multidisciplinary staff the need to search for evidence that can help professionals to plan and develop a practice of excellence in their actions, providing safe and quality assistance ${ }^{(1-2)}$.

THx is a complex surgical procedure that consists of removing the sick liver to place a healthy liver, which causes several clinical and hemodynamic changes in the immediate postoperative period. Specific care of the health staff in inpatient units, as well as thorough care for patients and families at home, are necessary to provide better quality of life, graft survival, minimization of injuries and post-transplant complications ${ }^{(3)}$.

During care transition between hospital discharge and readaptation to the new reality at home, patients and families may face complications related to $\mathrm{THx}$. The most common complications refer to increased appetite, diarrhea or constipation, nausea and vomiting, anxiety, stress, emotional, neurological, pulmonary, respiratory, renal changes, hyperlipidemia, hypertension, skin cancer, and hyperglycemia. The most frequent complications involve rejections and opportunistic infections. Such situations, when not identified and treated in a timely manner, can lead patients to other comorbidities, frequent readmissions or even death ${ }^{(2,4)}$.

In the daily adaptation to the new reality at home, adult patients experience different cares, which involve personal and environmental hygiene, use of immunosuppressants, glycemia check, use of insulin, control of vital signs, measurement of diuresis and others that may arise. Therefore, they experience uncertainties, fears and doubts regarding the execution of care, daily controls, signs and symptoms that may indicate complications, in addition to the overload of activities, stress and emotional impact in adapting to this new routine ${ }^{(5)}$.

Furthermore, it is important to highlight factors related to low adherence to treatment in care transition from hospital to home after THx. Studies point out personal risk factors, evidenced by problems or lack of social support, lack of information, use of several drugs simultaneously, diagnosis of mental disorder, use of alcohol and other drugs. It is necessary to emphasize the relevance that the educational process conducted by staff has at that moment, by making understandable continuity of treatment and the role of a support network in continuity of home care $^{(6-7)}$. Correct adherence to treatment is directed to planning care transition, educational interventions by staff, adoption of an individual therapeutic plan, alteration of the immunosuppressive regime, emotional and psychological support and support network strengthening ${ }^{(2,4)}$.

Considering this setting, the multidisciplinary staff involved in care transition needs to be able to plan, organize and teach these people in order to prepare them to return home and present the new health reality, enabling patients and graft survival, in addition to minimizing the risk of complications that may arise at home. It is essential that the health staff is supported by guides, protocols, standard operating procedures and guidelines, which can support professionals in planning and continuing home care.
Moreover, these materials provide strong evidence regarding the implementation of health actions by professionals in activity of daily living, safety, effectiveness, quality and good practices in continuity of health care for these patients ${ }^{(8)}$.

Good practices direct care to promote safety, improvement and strategic actions aimed at impacting both the health system results and the care developed. Still, they ensure care anchored in knowledge, ethics, respect, safety and scientific support through evidence. In this perspective and considering the need for safety in care transition for patients undergoing $\mathrm{THx}$, it is understood that good practices promote the best possible results in health care for these patients in the system ${ }^{(9)}$. In a safe care setting, good practices allow patients, families and a multidisciplinary staff to develop excellence in continuity of treatment at home for patients undergoing $\mathrm{TH}$.

Due to the need for good practices in care transition for these patients and considering the scarcity of studies that portray the guidelines that must be shared with patients in this context, identified through two literature reviews $s^{(2,10)}$, it is understood as fundamental to elaborate and use a guide of good practices in the planning of hospital discharge in THx capable of pointing out safe care actions in this process. The guide can assist staff in planning, organizing, communicating, interpersonal relationships with the health network, in addition to providing health education to adult patients undergoing $\mathrm{THx}$, support for self-care, guidance on the flow of continuity of care, as well as guide these people towards safe and effective care. Authors point out that transition from hospital to home should involve planned health actions capable of ensuring continuity of care in the discharge process. Patient, family and health staff experience different moments of adjustments in their routines and patient care ${ }^{(11-12)}$.

Given the above, the guiding question of this study was: what information supports the development of a guide for care recommendations for good practices for care transition to adult patients undergoing liver transplantation?

\section{OBJECTIVES}

To develop a guide of care recommendations for good practices in care transition for adult patients undergoing liver transplantation.

\section{METHODS}

\section{Ethical aspects}

This study was approved by the Research Ethics Committee with Human Beings of Universidade Federal de Santa Catarina. Participants received information about the research objectives, with a subsequent invitation to participate in the study. When expressing interest, they signed an Informed Consent Form.

\section{Design, place of study and period}

This is a methodological study aiming at developing a guide with recommendations for care for good practices, which was developed in two stages: first stage - guide's content development - an integrative review to survey the scientific evidence and 
a qualitative study; second step - guide assessment process with care recommendations - the Appraisal of Guidelines for Research \& Evaluation (AGREE) ${ }^{(13)}$ was used in the updated version, II, as this is a method that aims to assess quality clinical guidelines and provide a methodological strategy for their development.

The integrative review was conducted between 2014 and 2019, in six stages ${ }^{(10)}$, in order to identify in national and international databases evidence capable of supporting the care recommendations in the guide for care transition. Subsequently, a qualitative research was developed between January and June 2019 with adult patients undergoing THx, seeking to identify patients' doubts, difficulties and experiences after hospital discharge. Regarding care assessment development of care recommendations, through AGREE ${ }^{(13)}$, it was carried out by three professionals with expertise in the field of transplantation using the 23 key items, categorized in six domains, in which each domain refers to a dimension quality of the guideline, which are: Domain 1 - scope and purpose; Domain 2 - stakeholder involvement; Domain 3 rigor of development; Domain 4 - clarity of presentation; Domain 5 - applicability; Domain 6 - editorial independence.

\section{Population and sample: inclusion and exclusion criteria}

For the integrative literature review, original research, protocols, guides, guidelines and discussion articles were included. Theses and dissertations, letters, editorials, studies that did not address the topic of interest were excluded.

The SCOPUS, Latin American and Caribbean Literature in Health Sciences (LILACS), Scientific Electronic Library Online (SciELO), Medical Literature Analysis and Retrieval System Online (MEDLINE), Cumulative Index to Nursing and Allied Health Literature (CINAHL), BDENF and Web of Science databases were defined.

A search strategy was elaborated for each database, with the help of a librarian, namely: (("Liver Transplantation" OR "Liver Transplantations" OR "Hepatic Transplantation" OR "Hepatic Transplantations" OR "Liver Grafting" OR "Liver Diseases" OR "Liver Disease" OR "Liver Dysfunction" OR "Liver Dysfunctions") AND ("Nursing Care" OR "Postoperative Care" OR "Postoperative Procedures" OR "Postoperative Procedure"OR"Patient Discharge" OR "Patient Discharges" OR “Discharge Planning" OR "Discharge Plannings" OR "Discharged from Hospital"))(10).

As for the qualitative study, the target population focused on adult patients undergoing $\mathrm{THx}$ in a referral hospital in southern Brazil. Adult patients who underwent transplantation between the years 2012 and 2018 and who followed outpatient treatment with the multidisciplinary staff during the period of data collection were included. Patients who underwent transplantation in another hospital and received only outpatient care with staff were excluded.

Assessment of care recommendations was carried out by three professionals with expertise in the field of transplantation, as recommended by the methodological framework. Evaluators with experience in the transplant field for more than five years, who work in care practice or have worked with transplant and who have published articles related to the topic were selected. To identify professionals, keywords (transplant, liver transplant and liver transplant) were searched in the Lattes Curriculum platform.
After filtering the criteria, 38 professionals remained. Contact was made via email with eight participants; however, only three expressed the agreement to proceed with the assessment due to the deadline for return. Evaluators are one from northeastern, one from southeastern and one from southern Brazil.

\section{Study protocol}

The integrative literature review followed the steps: (1) Research question development; (2) Development of criteria for searching the literature; (3) Data collection; (4) Critical analysis of material obtained; (5) Careful assessment and interpretation of information obtained; (6) Presentation of results obtained ${ }^{(10)}$.

For qualitative research, data collection was conducted by the researchers themselves in a reserved space at a transplant center. Post-transplant patients are treated on the same day of the week by the multidisciplinary staff, as needed for follow-up. First, patients were invited to participate in the research by one of the researchers. When expressing interest, they signed an Informed Consent Form, and, subsequently, a date and time was scheduled according to the availability of participants to develop the interview.

The interviews were semi-structured, conducted at a transplant center itself, in a private place with privacy and an average time of 30 minutes. They were guided by the following questions: how was your postoperative liver transplant? What are the main health needs you had in your post-operative liver transplantation at the hospital and at home? What were the main doubts that arose in the discharge process? What were your main difficulties when returning home after hospital discharge? How are you experiencing post-transplant treatment? The interviews were recorded, transcribed and validated by participants. The printed transcript of the interview to participants was re-presented so that the data could be validated by them with corrections and additions, if they deemed necessary. Only after validation was the material analyzed. To identify participants, the letter $P$ was used, followed by a number corresponding to the order of the interview (e.g., P1, P2, and so on)).

To improve search for information, the researchers, after authorization from patients, participated in some consultations with the multidisciplinary staff and home visits, developing participant observation, seeking to identify patients' health needs when returning home. For identification, "OV" was used for participant observation in home visits and "AO" for participant observation in an outpatient clinic.

The guide preparation with the care recommendations required three meetings with the researchers to form care actions. The information obtained was read carefully, giving the utmost attention to the development of ambivalences. It is noteworthy that two of the researchers who participated and coordinated this stage have extensive care experience with $\mathrm{TH}$, in addition to developing research in this field for over 10 years; in addition, one of the researchers has been working for more than 18 years in care practice with $\mathrm{TH}$.

The care recommendation assessment process was carried out as follows: initially, the manuscript containing care recommendations was sent to the selected evaluators, together with 
the AGREE II evaluator's manual ${ }^{(13)}$. The manual contains, in detail, each key item and domain that needs to be considered; in addition, it instructs the evaluators to determine a grade ranging from one (strongly disagree: key item and domain in question were not covered) to seven (strongly agree: key item and domain are in agreement). Also, it is possible to insert comments at the end of each key item and domain.

After assessing the six domains, the evaluators rated the overall quality of the guideline between 1 (lowest possible quality) and 7 (highest possible quality) and also indicated whether or not to recommend using the guideline (yes; yes, with modifications; not). It was also possible for the evaluators to describe global notes about the recommendations and then their signatures.

\section{Analysis of results}

In the integrative literature review stage, the identified articles were submitted to analysis seeking to identify information with greater relevance. They were categorized in order to identify the care recommendations for care transition for patients undergoing transplantation ${ }^{(10)}$. Moreover, the selected articles were analyzed according to level of evidence ${ }^{(14)}$.

For qualitative research data analysis, Bardin's ${ }^{(15)}$ content analysis was used, in its thematic modality that includes: pre-analysis, from text skimming and corpus constitution; material exploration with coding, from text clipping in registration units; treatment of results obtained and interpretation, working with meanings emerging from the data. Afterwards, four categories emerged capable of supporting the care recommendations.

The construction of the care recommendations in this guide was directed at Care Transition Planning, Health Education for Self-Care, and Care Management, since both the literature review and the information obtained from participants directed to these topics. Each care recommendation was briefly described, with the sections highlighted in bold and grouped according to the category. We sought to present the data clearly and concisely.

As for assessment of care recommendations, after the evaluators' feedback, the researchers proceeded with data analysis. For this, AGREE II ${ }^{(13)}$ recommends that the following calculation be conducted to obtain the assessment scores for each domain:

$$
\frac{\text { core obtained-minimum score }}{\text { maximum score-minimum score }} \times 100
$$

Score obtained: sum of all the scores given by the evaluators for individual items; Maximum score: 7x number of items $\mathrm{x}$ number of evaluators; Minimum score: $1 \mathrm{x}$ number of items $\mathrm{x}$ number of evaluators.

The final result is given in a percentage value. The closer to $100 \%$, the higher the quality of the care recommendation.

\section{RESULTS}

The final sample of the integrative review consisted of 13 articles, the PubMed database $(n=7 ; 53.8 \%)$ had the largest number of articles and eight studies (61.5\%) were classified with level of evidence 5 . The main recommendations were for: warning signs for possible changes that may appear at home; recommendations for using medications - promoting self-management and adherence to treatment; daily activities and care at home - support and self-confidence and changes in body image; daily life - importance of a support network ${ }^{(10)}$.

Twenty patients participated in the research, with an average age of 55.4 years, $75 \%$ men, $70 \%$ married, $50 \%$ with completed high school and $25 \%$ retired. The average post-THx time was 996 days, and $40 \%$ had an indication for $\mathrm{TH} x$ cirrhosis caused by the $C$ virus.

Analysis of the material obtained from interviews and participant observations guided the formation of four categories: discharge planning; health education; self-care; follow-up with the multidisciplinary health staff, as shown in Figure 1.

\section{CARE TRANSITION}

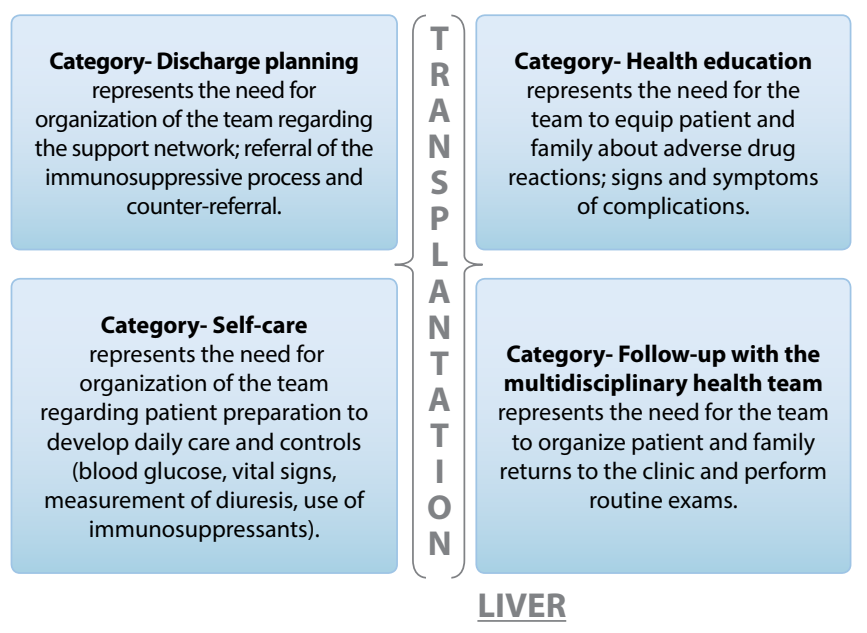

Figure 1 - Synthesis of the categories elaborated from the interviews and participant observations, Florianópolis, Santa Catarina, Brazil, 2020

With regard to the elaboration of a good practice guide based on care recommendations, Chart 1 shows the union of the information obtained from the literature review and qualitative study; they supported the elaboration of care recommendations for the Health Education for Self-Care axis. In this chart, it is possible to notice that, for the formation of this axis, in addition to the evidence, the content of two categories of the qualitative study was used to provide greater support and robustness to this care axis.

Due to a large volume of information, it was decided to present only one chart as an example. The first column represents the evidence obtained in the literature, while the second column presents the respective patients' statements and participant observation, supporting the axis formation and their respective care recommendations.

As for the recommendations, it was decided to present in the chart format (Chart 2) the care guide for good practices in transition from hospital discharge of adult patients undergoing THx. The guide and its recommendations have three central axes, obtained based on the recommendations and evidence found in the study: Care Transition Planning; Health Education for Self-Care; Care Management. Each of the central themes presents respective subtopics and care recommendations. 
Regarding the guide quality assessment according to AGREE II, the highest score (100\%) was obtained in Domain 1 as a result, i.e., all evaluators fully agreed with the fulfillment of each item in this domain. Domain 5 also had the lowest score, $91.6 \%$. The other domains obtained the following scores: Domain 2,96.3\%; Domain 3, 93\%; Domain 4, 98.1\%; Domain 6, 97.2\%.

It is noteworthy that even the lowest score remained above $90 \%$, evidencing the high quality of the elaboration of the recommendations. Still, all indexes indicate absence of critical flaws observed by evaluators with experience and expertise in the field of transplantations, proving their high potential to impact care practice in this setting.

Finally, two of the evaluators registered the index 7 as a global assessment, indicating that the entire guide has the highest possible quality; an appraiser registered the index 6 . There was no low index reported by the appraisers. Along with this, it is highlighted that the three evaluators recommended using the care recommendation guide for good practices in transition from hospital discharge of adult patients submitted to $\mathrm{THx}$, describing that it is a tool that will support and strengthen the multidisciplinary staff in care transition with liver transplant recipients and family.

\section{DISCUSSION}

$\mathrm{TH}$ is one of the most complex procedures in medication and involves significant changes in the daily lives of those involved. In this perspective, the findings point out that patients and families must be inserted early into the new reality of transplant, i.e., when they are still on the waiting list, since, after the inclusion on the list, patients have no date and neither time to perform the procedure. Therefore, it is essential that the health staff gradually make the information feasible so that patients and family adapt to the new reality. ${ }^{(5)}$.

During analysis of the study's findings, both in terms of evidence and patient participation and participant observation, it is clear that the health staff becomes a promoter and responsible for safe care, especially with regard to some care to be developed at home ${ }^{(21-22)}$. In all the information bases obtained, some difficulties faced, as well as some care needs, stood out, such as the use of immunosuppressants, daily care, glycemia check and insulin application. It is noteworthy that many patients, prior to transplantation, did not have the need to use insulin, nor did they need to develop health care at home in relation to glycemic control. However, after THx, there is a need for this care to be performed, in addition to daily caution to verify that the values obtained in the measurements are ideal.

Chart 1 - Presentation of the data obtained in the study for the formulation of recommendations in the Health Education for Self-Care axis

\begin{tabular}{|c|c|c|}
\hline \multicolumn{3}{|l|}{ Health Education for Self-Care Axis } \\
\hline Evidence (integrative review) & \multicolumn{2}{|l|}{ Category: Self-care } \\
\hline \multirow{3}{*}{$\begin{array}{l}\text { At home, patients present increased appetite, diarrhea or } \\
\text { constipation, nausea and vomiting, changes in body image, } \\
\text { body sensation, sexuality, decreased libido, altered sleep } \\
\text { pattern and wakefulness, and lower limbs edema (Author }{ }^{(16)}- \\
\text { level of evidence: } \mathrm{V} \text { ). } \\
\text { Daily control should be instructed to patients in hospital } \\
\text { discharge for successful transplantation and early detection of } \\
\text { adverse events (Author }{ }^{(17)} \text { - level of evidence: } \mathrm{V} \text { ). }\end{array}$} & Patient & Participant note \\
\hline & $\begin{array}{l}\text { I feel very tired. I got weight. I don't exercise, I'm } \\
\text { inactive, I need to take care of myself. They asked } \\
\text { me this. (Patient 4) }\end{array}$ & $\begin{array}{l}\text { Virtually no patient scored } \\
\text { the development of physical } \\
\text { activity (OA). }\end{array}$ \\
\hline & $\begin{array}{l}\text { I was asked to verify the temperature, assess the } \\
\text { pee, see weight, diabetes. I had to turn around, do } \\
\text { my best to take care of myself. (Patient 14) } \\
\text { I had to take care, especially with the use of } \\
\text { medications and with food, with food it was too } \\
\text { much. (Patient 8) }\end{array}$ & $\begin{array}{l}\text { Many patients took care at } \\
\text { home for personal hygiene and } \\
\text { medication use (OV). }\end{array}$ \\
\hline Evidence (integrative review) & \multicolumn{2}{|l|}{ Category: Health Education } \\
\hline $\begin{array}{l}\text { Clarification on complications to avoid injuries (Author }{ }^{(18)} \text { - } \\
\text { level of evidence: IV). } \\
\text { Nurses should provide information to patients and family } \\
\text { members about status of employment and possible problems } \\
\text { after transplantation (Author }{ }^{(19)} \text { - level of evidence: V). } \\
\text { Transplant patients may have pre-existing Diabetes Mellitus. } \\
\text { For this, it is necessary to teach patients and family to perform } \\
\text { the correct control of blood glucose, as well as the application } \\
\text { of insulin (Author }{ }^{(20)} \text { - level of evidence: V). } \\
\text { The main nursing diagnoses for hospital discharge from liver } \\
\text { transplantation are Risk for infection, Risk for unstable blood } \\
\text { glucose and Risk for impaired liver function (Author }{ }^{(16)}-\text { level of } \\
\text { evidence V). } \\
\text { Transition to home is a complex moment, with the increased } \\
\text { risk of medication errors due to incorrect or incomplete } \\
\text { transfer of information, besides involving multiple actions, } \\
\text { such as multidisciplinary and interinstitutional action (Author }{ }^{(7)} \\
\text { - level of evidence: } \mathrm{V} \text { ). }\end{array}$ & $\begin{array}{l}\text { It's a lot of medication time, it has all kinds of } \\
\text { control, food restriction, it's a lot. It was very difficult } \\
\text { to know how to do all this. (Patient 3) } \\
\text { At first, I had to swallow that bunch of pill. It was } \\
\text { about } 15 \text { at a time, I was afraid to take it and I } \\
\text { doubt ed whether It was right even. (Patient 5) } \\
\text { I had to turn around to apply insulin alone. I believe } \\
\text { loften mistook the diabetes test. (Patient 12) }\end{array}$ & $\begin{array}{l}\text { The greatest perceived fragility } \\
\text { was with mouth hygiene. } \\
\text { They have doubts about the } \\
\text { frequency and sequence of } \\
\text { brushing }\left(\mathrm{OV}^{*}\right) \text {. } \\
\text { Blood glucose at home was } \\
\text { being checked at the wrong } \\
\text { times. There was a situation } \\
\text { where the device was not } \\
\text { calibrated (OV). } \\
\text { It was possible to notice little } \\
\text { practice of patients regarding } \\
\text { using blood glucose apparatus } \\
\text { and the application of insulin } \\
\text { (OV). } \\
\text { On the return to the outpatient } \\
\text { clinic, some controls were not } \\
\text { recorded }\left(\mathrm{OA}^{* *}\right) \text {. }\end{array}$ \\
\hline
\end{tabular}

Note: *OV refers to participant observation in the home visit; ${ }^{* *}$ OA refers to participant observation in the outpatient clinic. 
Chart 2 - Guide of recommendations for good practices in care transition from hospital discharge of patients undergoing liver transplantation

\begin{tabular}{|c|c|c|}
\hline CARE TRANSITION PLANNING & HEALTH EDUCATION FOR SELF-CARE & CARE MANAGEMENT \\
\hline \multirow{2}{*}{$\begin{array}{l}\text { Support network training: } \\
\text { - Identify in the family people with greater } \\
\text { affinity to develop home care. } \\
\text { - Propose to organize with the family range } \\
\text { of caregivers. } \\
\text { - Organize with support network and social } \\
\text { worker the place to receive patients after } \\
\text { discharge; } \\
\text { - Promote closer ties of family members, } \\
\text { adjusting the relationship with the family. } \\
\text { Organize support network according to } \\
\text { each patient's needs. }\end{array}$} & $\begin{array}{l}\text { CAUTION: To start preparing patients for home } \\
\text { activities soon after patients' return to the } \\
\text { hospitalization unit, after patients are not in pain and } \\
\text { able to listen to the guidelines. }\end{array}$ & \multirow{3}{*}{$\begin{array}{l}\text { Patient: } \\
\text { - Patients should check daily if all } \\
\text { care was performed in the morning, } \\
\text { afternoon and evening. } \\
\text { Multidisciplinary transplant staff: } \\
\text { - Make contact by technological } \\
\text { means checking if the care is being } \\
\text { performed according to guidance. } \\
\text { - Make home visit if possible. } \\
\text { Primary Care Staff: } \\
\text { - Make weekly visits and promote } \\
\text { adjustment in care if necessary. }\end{array}$} \\
\hline & \multirow{2}{*}{$\begin{array}{l}\text { Alert for signs of complications: } \\
\text { - Clarify to patients about the possible complications (most } \\
\text { common) signs and symptoms, such as preventing them, } \\
\text { time that these can last and what conducts to adopt in } \\
\text { the face of such a situation. } \\
\text { - Point out to patients which are the most common } \\
\text { possible complications to arise at home (especially } \\
\text { rejection and opportunistic infections), signs and } \\
\text { symptoms of them, how to prevent them and what } \\
\text { behaviors to adopt in face of such situation. }\end{array}$} & \\
\hline \multirow[b]{2}{*}{$\begin{array}{l}\text { Approach with primary care staff } \\
\text { (counter-referral): } \\
\text { - Make contact with patients' referral unit, } \\
\text { passing all patient information: social data, } \\
\text { clinical situation, care needs, need for } \\
\text { materials and medications. } \\
\text { - Forward via online prescriptions of } \\
\text { medications and materials; } \\
\text { - Agree with this staff date and time so that } \\
\text { a family member can pick up materials } \\
\text { and medications. } \\
\text { - Schedule with staff the date of home visit } \\
\text { that must be carried out by them in the } \\
\text { first week after discharge. }\end{array}$} & & \\
\hline & \multirow{2}{*}{$\begin{array}{l}\text { Daily care activities - } \\
\text { Medications: } \\
\text { - Create an enlarged table that provides guidance on } \\
\text { times, doses and adverse effects. Indicate differently in } \\
\text { the table which are the immunosuppressants. } \\
\text { Control and daily care: } \\
\text { - Develop strategies to teach the development of } \\
\text { hemoglycotest and insulin application, as well } \\
\text { as the times to be performed and normal values. } \\
\text { Encourage the performance of this care even during } \\
\text { hospitalization so that staff can manage. } \\
\text { - Teach in detail how to check vital signs and how to } \\
\text { control temperature. } \\
\text { - Teach how to measure and store diuresis. } \\
\text { - Explain to patients how they should watch for warning } \\
\text { signs in the body for edema, itching, blemishes and } \\
\text { others. } \\
\text { - Develop an individual care plan for each patient } \\
\text { regarding their own hygiene. Observation: It is } \\
\text { necessary to adapt this plan according to patients' } \\
\text { social conditions, educational level and performance } \\
\text { capacity. }\end{array}$} & $\begin{array}{l}\text { aily care activities - } \\
\text { ood consumption: } \\
\text { Raise awareness and teach about the } \\
\text { need to consume only cooked foods. } \\
\text { Explain clearly and simply how food } \\
\text { should be sanitized when arriving } \\
\text { from shopping as well as how to } \\
\text { proceed with the preparation and how } \\
\text { to store. } \\
\text { Explain about fluid intake and } \\
\text { adequate daily quantity. }\end{array}$ \\
\hline $\begin{array}{l}\text { Referral of the special medication process } \\
\text { (immunosuppressants): } \\
\text { - Request with medical staff the completion } \\
\text { of the process, prescriptions, forwarding } \\
\text { to the health network. } \\
\text { - Organize immunosuppressants for home } \\
\text { use at doses for one month. } \\
\text { - Teach where and when the } \\
\text { family member will withdraw the } \\
\text { immunosuppressive medications. }\end{array}$ & & $\begin{array}{l}\text { Development of physical activities: } \\
\text { - Develop a plan of daily physical } \\
\text { activities. } \\
\text { - Show patients what daily activities } \\
\text { they can and should do at home. } \\
\text { Socialization with support network: } \\
\text { - Explain in detail, in a simple way, that } \\
\text { in the first months the orientation is } \\
\text { that there is not contact with many } \\
\text { different people. However, they may } \\
\text { have brief contacts, keeping their } \\
\text { distance and in a ventilated place. }\end{array}$ \\
\hline
\end{tabular}

Authors point out the importance and responsibility of the health staff to develop strategies that can support and support these patients on their return to home. Furthermore, it is these professionals who have knowledge and specifics about home care to be performed and managed by patients and family, with support from Primary Health Care ${ }^{(2,23)}$.

Understanding patients' health needs in the residential environment is important. THx is a highly complex procedure and; in addition, in the home environment, patients are still subject to complications, especially if treatment is not properly adhered to, affecting graft survival ${ }^{(3,5,24)}$. In this study, in both searches for information, both in the integrative review and in the qualitative research, the data direct the development of complex home care, at the same time that they point out patients' fragility before this new setting. Although the information obtained reveals the multidisciplinary staff's effort in organizing health education, self-care and follow-up after hospital discharge, there are still doubts, uncertainties, insecurities, and fear before a new routine. Considering the findings and seeking to develop good practices in care transition, the recommendations guide points out three axes of care with their due recommendations.
In the Care Transition Planning axis, the recommendations revealed the importance of staff organizing support network formation prior to hospital discharge. When returning home, the presence of close people who can help this patient is essential. Even if he is prepared for self-care, there are activities that cannot be performed by him in the first days. This axis proposes to bring patients and family closer to the Primary Care network through counter-referral and support network (family, friends, neighbors). However, it should be noted that the multidisciplinary tertiary care staff has knowledge of $\mathrm{THx}$, history of patients, in addition to the care needs to be performed at home. Thus, it is necessary that they make contact with other Primary Care professionals to teach and provide all care to be developed at home so that this staff can support patients and families.

Also, in this regard, care recommendations continue with the organization of immunosuppressants for discharge. This emerges as an important and indispensable care for the safety of patients and continuity of treatment. The use of immunosuppressants must be continuous, as incorrect doses or failure to use implies graft loss ${ }^{(4,22)}$. Authors ${ }^{(4,22)}$ point out nurses' commitment and responsibility in managing disposition and distribution of these 
medications to THx patients, in addition to the pharmacist, who is committed to ensuring quality of care and patient safety in using medications. Immunosuppressants are essential to avoid rejection; however, they have side effects that can also aggravate health. Thus, the care recommendations in the guide point to the importance of patients receiving these drugs as soon as possible so that there are no insufficient doses or even a lack of medication during treatment.

In the Health Education for Self-Care axis, the findings show the need to insert patients into their self-care as soon as possible. Both in the information obtained in the literature review and in the qualitative research, there are data that reveal that there are several care to be developed at home and that there is a need for patients to assist caregivers and take on these activities as soon as possible, since the caregiver does not will be present at all times at home. Still, it is noteworthy that in the post-transplantation, complications may arise; therefore, patients need to be aware of the warning signs and symptoms for health care to be performed with a view to organ maintenance, quality of life and graft survival.

In this sense, this axis of care shows that patients need to be able and safe to recognize signs of health problems, in addition to being able to develop home care. Thus, it is understood that effective health education enables patients return to home, while promoting the empowerment of patients, families and support network for the execution of care. Other authors corroborate this axis by pointing out that self-care enables patients to preserve health, prevent diseases, perform self-management, self-monitoring, symptom management, thus allowing them to manage their own care ${ }^{(24-26)}$. When patients and their support network understand the new post-transplant reality, they adhere better to treatment and cooperate effectively. These actions provide satisfactory quality of life, graft survival, less risk of complications and frequent readmissions ${ }^{(26-28)}$.

From the perspective of nurses' assistance, this axis of care highlights professionals, since health education is one of nurses' skills that needs to be trained and updated to teach after transplant about the signs and symptoms of rejection and infections, possible complications and pharmacological interactions. It is verified the importance of the performance of this professional to manage the care of transplant patients, favoring quality of life through safe and effective information ${ }^{(29-30)}$.

In the Health Education for Self-Care axis, the recommendations point to the importance of staff paying attention to teach, explain and show how each home care activity should be conducted. Patients need to leave the hospital knowing how to develop this care step by step, and, for this, staff needs to show patients how to do it and in what sequence, requesting that, after the guidelines, they develop the care. In this way, it will be possible to make sure that care is being performed correctly, providing security for those who perform it and for those who need to manage remotely after discharge. The development of this home care is one of the main factors of fear and concern of patients, which can lead to low adherence to treatment ${ }^{(2,5,7)}$.

In this health education setting, the effective participation of several professionals stands out, such as physician, pharmacist, nutritionist, social worker and psychologist. These professionals, together with nurses, develop contributions for patients and family in coping with home care ${ }^{(8,21)}$. Nurses, integrating the multidisciplinary staff, often instinctively take over the leadership role in this process through verbal and non-verbal communication skills, aiming at comprehensive and cohesive care for patients. These professional also supports building strategies to provide patients measures for a healthy lifestyle and control of functions ${ }^{(7)}$.

Finally, the Care Management axis brings the obligation and the duty of home care management by both patients, support network, THx multidisciplinary staff and the Primary Care staff. Everyone needs to speak the same language when talking about post-THx home care. The involvement of the multidisciplinary and the Primary Care staffs is directly related to good practices and patient safety, as it relates to guidelines based on scientific consensus that ensure effective follow-up by qualified professionals at the discharge of post-transplant patients, minimizing the negative events that can occur due to discontinuity of care ${ }^{(21)}$.

To develop care recommendations in this field, the possibility of understanding that there are doubts both by patients and by their support network regarding food consumption and the development of physical activities was considered. In view of this setting, the care recommendations in this axis point to the importance of establishing plans, so that, with safety, food hygiene care, menu options and choice of physical activities with limits become factors that contribute to graft and quality of life maintenance. Healthy living habits, combined with a rehabilitation plan, provide effective improvement in post-transplantation ${ }^{(12,16-17)}$.

However, for there to be an adequate and effective home care plan, there must be an interconnection between the different levels of health care (primary, secondary, and tertiary care), which belong to the Health Care Networks (RAS - Rede de Atenção à Saúde).

Through counter-referral, patients are referred resolutely by the RAS, aiming at continuity of care in the home environment and making it more effective and comprehensive ${ }^{(31)}$. For continuity of care, it is necessary that everyone involved has the same knowledge of what activities and care should be performed at home. If there are divergences in the guidelines provided by health professionals, especially at different levels of care, there may be distrust of patients and low adherence to treatment. Ensuring that care is performed correctly at home is challenging for the health staff. Thus, it is understood that the Care Management axis brings implicit recommendations that can guide everyone involved in care transition, since they propose standardized language. However, it is worth highlighting the findings of other studies that point out that it is necessary, prudent and important that the RAS staff is engaged, involved and committed in all spheres of health care. Only then will self-care and adherence to treatment be effective(2,32-33).

Concerning the care recommendation assessment in this guide, all domains had scores greater than $90 \%$, added to the overall assessment record of the three evaluators having remained between 6 and 7, recommending using the guide for good practices in care transition from discharge treatment of adult patients undergoing $\mathrm{TH}$.

This recommendations guide is considered to meet the criteria of the established method, supporting good health care practices with patients undergoing THx. Still, the validity of these 
evaluated care recommendations stands out, since other studies have shown score results between $70 \%$ and $100 \%{ }^{(34-35)}$. Thus, it is understood that such a care tool will support and strengthen the multidisciplinary staff in care transition with liver transplant recipients and family.

It should be noted that there was no funding for the development of this study as well as the authors declare that there is no conflict of interest. Furthermore, for the applicability of this research in the multidisciplinary staff's practice with regard to transition from hospital to home care, there is no need for extra financial resources. It is advised, however, that the multidisciplinary staff, having the care recommendations in hand, can promote discussions in the work environment to implement the recommendations.

The recommendations contained in the guide to good practices in care transition from hospital discharge of adult patients undergoing liver transplantation will need to be updated five years after the publication of this study, considering that scientific knowledge is dynamic. Therefore, future studies that seek updated care recommendations and corresponding to the new reality that will be experienced in the $\mathrm{TH}$ x setting are suggested.

\section{Study limitations}

One of the limiting factors in the search for information in the literature was the low levels of evidence. Faced with this, there was difficulty in formulating strong evidence-based care recommendations. Another limitation pointed out in the study is related to the difficulty in organizing conversations with the institution's multidisciplinary staff to discuss the recommendations and thus apply the adjustments.

\section{Contributions to health}

Access to the guide for care recommendations for good practices in care transition for adult patients undergoing liver transplantation by professionals from the THx multidisciplinary staff and the primary care staff makes it possible to promote care transition safely and effectively, due to all professionals follow the same language and evidence. Along with this, the contributions for patients that will receive sequential, clear and simple guidance and information are highlighted, minimizing the risk of adverse events, promoting quality of life and graft survival. Still, it is important to point out that good practices lead the health staff to develop evidence-based care.

\section{FINAL CONSIDERATIONS}

The study aimed to develop a guide for care recommendations for good practices in care transition for patients undergoing liver transplantation. To consolidate this care tool, information was obtained through evidence, patient participation and participant observation by researchers.

The findings reveal the indispensability of the multidisciplinary staff to carefully organize and plan care transition. In this organization, staff must pay attention to prepare patients' support network, carry out counter-referral with Primary Care, in addition to providing all materials, medications, and other supplies that may be needed at home. Still, the recommendations massively emphasize the obligation for staff to present, teach and show patients how each care should be performed at home, in addition to ensuring that they know how to identify signs and symptoms of complications. Only then will patients be able to develop self-care.

Staff is protected from the need to plan the physical and home activities that patients will be able to perform. It is evident that, in the discharge process, information must be provided to patients undergoing THx and their families. However, in addition to the guidelines, staff, together with patients, needs to manage and adapt care actions in order to certify adherence to treatment and continuity of this treatment, seeking to maintain quality of life and graft survival.

Finally, it is highlighted that the elaboration of care recommendations, following the AGREE II methodological framework, supports and subsidizes the multidisciplinary staff to act with higher quality, since it supports care actions based on scientific evidence developed with rigor and validated by professionals with expertise in the field, bringing safety to patients, central figure of health care.

\section{REFERENCES}

1. Associação Brasileira de Transplante de Órgãos (ABTO). Registro Brasileiro de Transplantes. Dimensionamento dos Transplantes no Brasil e em cada estado (2012-2019) [Internet]. ABTO. 2019 [cited 2020 May 30];4:95-1. Available from: http://www.abto.org.br/abtov03/Upload/file/ RBT/2019/RBT-2019-leitura.pdf

2. Oliveira PC, Deta FP, Paglione HB, Mucci S, Schirmer J, Roza BA. Adherence to liver transplantation treatment: an integrative review. Cogitare Enferm. 2019;24:e58326. https://doi.org/10.5380/ce.v24i0.58326

3. Mcginnis CW, Hays SM. Adults with liver failure in the intensive care unit: a transplant primer for nurses. Crit Care Nurs Clin North Am. 2018;32(1):137-48. https://doi.org/10.1016/j.cnc.2017.10.012

4. Morais EM, Conrad D, Machado GC, Abreu MO, Matos EM, Cruz SAC. Postoperative complications of liver transplant: evidence for the optimization of nursing care. Rev Pesqui: Cuid Fundam. 2017;9(4):1007-999. https://doi.org/10.9789/2175-5361.2017.v9i4.999-1007

5. Knihs NS, Lorençoni BP, Pessoa JLE, Paim SMS, Ramos SF, Martins MS, et al. Health needs of patients undergoing liver transplant from the context of hospital discharge. Transplant Proc. 2020;XX:1-6. https://doi.org/10.1016/j.transproceed.2020.02.022

6. Oliveira RA, Turrini RNT, Poveda VB. Adherence to immunosuppressive therapy following liver transplantation: an integrative review. Rev Latino-Am Enferm. 2016;24:e2778. https://doi.org/10.1590/1518-8345.1072.2778 
7. Oliveira PC, Paglione HB, Silva e Silva V, Schirmer J, Roza BA. Measurement of non-adherence to immunosuppressive medication in liver transplantation recipients. Acta Paul Enferm. 2019;32(3):319-26. doi:10.1590/1982-0194201900044

8. Enam A, Torres-Bonilla J, Eriksson H. Evidence-Based Evaluation of eHealth Interventions: systematic literature review. J Med Internet Res. 2018;20(11):e10971. https://doi.org/10.2196/10971

9. Vieira AN, Petry S, Padilha MI. Best practices in historical studies of nursing and health (1999-2017). Rev Bras Enferm. 2019;72(4):973-8. https://doi.org/10.1590/0034-7167-2018-0538

10. Wachholz LF, Knihs NS, Martins SR, Magalhães ALP, Brehmer LCF, Martins MS. Hospital discharge of liver transplantation patient: an integrative review. Esc Anna Nery. 2020;24(4):e20190346. https://doi.org/10.1590/2177-9465-EAN-2019-0346

11. Ferrazo S. Transplante hepático na perspectiva da bioética: um estudo de caso [Dissertação] [Internet]. Curso de Enfermagem, Centro de Ciências da Saúde, Universidade Federal de Santa Catarina, Florianópolis. 2014 [cited 2020 May 14]. Available from: https://repositorio.ufsc. $\mathrm{br} / \mathrm{handle} / 123456789 / 129692$

12. Lorenzini $E$, Banner D, Plamondon $K$, Oelke N. A call for knowledge translation in nursing research. Texto Contexto Enferm. 2019;28:e20190104. https://doi.org/10.1590/1980-265x-tce-2019-0001-0004

13. Brouwers M, Kho ME, Browman GP, Burgers JS, Cluzeau F, Feder G, et al. AGREE Next Steps Consortium. AGREE II: Advancing guideline development, reporting and evaluation in healthcare. Can Med Assoc J. 2010. https://doi.org/10.1503/cmaj.090449

14. Melnyk BM, Fineout-Overholt E. Evidence-based practice in nursing and healthcare: a guide to best practice. Philadelphia, PA: Lippincott, Williams \& Wilkins; 2011.

15. Bardin L. Content analysis. São Paulo: Edições 70; 2011; 229 p.

16. Oliveira NSP, Oliveira TM, Corrêa AR, Tiensoli SD, Bonisson PLV, Guimarães GL, et al. Nursing diagnoses of post-liver transplantation patients in outpatient follow-up. Cogitare Enferm. 2019;24:e59149. https://doi.org/10.5380/ce.v24i0.59149

17. Beckmann S, Künzler-Heule P, Biotti B. Mastering together the highs and lows: patients' and caregivers' perceptions of self-management in the course of liver transplantation. Prog Transplant. 2016;26(3):215-23. https://doi.org/10.1177/152692481665476

18. Bardet JD, Charpiat B, Bedouch P, Rebillon M, Ducerf C, Gauchet A, et al. Illness representation and treatment beliefs in liver transplantation: an exploratory qualitative study. Elsevier BV. 2014;72(5):375-87. https://doi.org/10.1016/j.pharma.2014.05.005

19. Moayed MS, Ebadi A, Khodaveisi M, Toosi MN, Soltanian AR, Khatiban M. Factors influencing health self-management in adherence to care and treatment among the recipients of liver transplantation. Patient Prefer Adherence. 2018;12:2425-36. https://doi.org/10.2147/PPA.S180341

20. Wallia A, Illuri V, Molitch M. Diabetes care after transplant. Med Clin North Am. 2016;100(3):535-50. https://doi.org/10.1016/j. mcna.2016.01.005

21. Lima LF, Martins BCC, Oliveira FRP, Cavalcante RMA, Magalhães VP, Firmino PYM, et al. Pharmaceutical orientation at hospital discharge of transplant patients: strategy for patient safety. Einstein. 2016;14(3):359-65. https://doi.org/10.1590/S1679-45082016AO3481

22. Melo DO, Castro LLC. Pharmacist's contribution to the promotion of access and rational use of essential medicines in SUS. Ciênc Saúde Colet. 2017;22(1):235-44. https://doi.org/10.1590/1413-81232017221.16202015

23. Carlos PM, Rocha, FN. Psychologist's performance in postmortem organ transplant. Rev Mosaico. 2019;10(2):32-7. https://doi.org/10.21727/ rm.v10i2.1786

24. Aguiar MIF, Alves NP, Braga VAB, Souza AMA, Araújo MAM, Almeida PC. Psychosocial aspects of quality of life of hepatic transplant receivers. Texto Contexto Enferm. 2018;27(2):e3730016. https://doi.org/10.1590/0104-070720180003730016

25. Menezes LCG, Moura NS, Vieira LA, Barros AA, Araújo ESS, Guedes MVC. Action research: self-care practices of people with diabetic foot. Rev Enferm UFPE. 2017;11(Supl. 9):3558-66. https://doi.org/10.5205/reuol.10620-94529-1-SM.1109sup2017

26. Santos BP, Schwartz E, Beuter M, Muniz RM, Echevarría-Guanilo ME, Viegas AC. Consequences attributed to kidney transplantation: critical incident technique. Texto Contexto Enferm. 2015;24(3):748-55. https://doi.org/10.1590/0104-07072015000270014

27. Jam JG. Caregiver representations about their organization of family network after stroke. Rev Cuba Enferm [Internet]. 2017 [cited 25 May 2020];33(3). Available from: http://revenfermeria.sld.cu/index.php/enf/article/view/918

28. Vesco NL, Fragoso LVC, Beserra FM, Aguiar MIF, Alves NP, Bonates LAM. Healthcare-related infections and factors associated to the postoperative period of liver transplantation. Texto Contexto Enferm. 2018;27(3):e2150017. https://doi.org/10.1590/0104-070720180002150017

29. Nogueira MA, Flexa JKM, Montelo IR, Lima LS, Maciel DO, Sá AMM. Donation of organs and tissues for transplantation: theoretical contributions. Rev Recien [Internet]. 2017 [cited 25 May 2020];7(20):58-69. Available from: https://www.recien.com.br/index.php/Recien/ article/view/226

30. Quaglio WH, Bueno SMV, Almeida EC. Difficulties faced and actions evidenced in the nurses' performance regarding organ donation: integrative review. Arq Ciênc Saúde UNIPAR. 2017;21(1):53-8. https://doi.org/10.25110/arqsaude.v21i1.2017.6076

31. Hermida PMV, Nascimento ERP, Echevarría-Guanilo ME, Andrade SR, Ortiga AMB. Counter-referral in Emergency Care Units: discourse of the collective speech. Rev Bras Enferm. 2019;72(Suppl 1):143-50. https://doi.org/10.1590/0034-7167-2018-0023

32. Maffissoni AL, Vendruscolo C, Trindade LL, Zocche DAA. Health care networks in nursing training: interpretations based on primary health care. Rev Cuid. 2018;9(3):2309-21. https://doi.org/10.15649/cuidarte.v9i3.549 
33. Mota L, Bastos F, Brito M. The liver transplant patient: characterization of the therapeutic regimen management style. Rev Enferm Ref. 2017;4(13):19-30. https://doi.org/10.12707/riv17006

34. Brasil RFG, Silva MJ, Moura ERF. Evaluation of the clinical protocol quality for family planning services of people living with HIV/AIDS. Rev EsC Enferm USP. 2018;52:e03335. https://doi.org/10.1590/S1980-220X2017008103335

35. Sousa DMN, Lima ACMACC, Vasconcelos CTM, Stein AT, Oriá MOB. Development of a clinical protocol for detection of cervical cancer precursor lesions. Rev Latino-Am Enfermagem. 2018;26:e2999. https://doi.org/10.1590/1518-8345.2340.2999 